\title{
Competition phase affect motivation and perceived performance but not the pre-competitive anxiety on professional dancers
}

\author{
Shaune E Fornaciari Silva ${ }^{\mathrm{a}, \mathrm{b}}$, Helio Serassuelo Junior ${ }^{\mathrm{b}}$, Marina Magatão ${ }^{\mathrm{a}}$, Ana Carolina Paludo ${ }^{\mathrm{a} *}$
}

\section{Keywords:}

Dance;

Competition;

Anxiety;

Performance.

Palavras Chave:

Dança;

Competição;

Ansiedade;

Desempenho.

\begin{abstract}
The aim of this study was to evaluate the effect of competition phase on pre-competitive anxiety, motivation and perceived of performance on professional contemporary dancers. Eight professional dancers from the same company were evaluated on basal condition, classificatory and final phase. Anxiety and motivation state were evaluated pre-competition and perceived of performance (PP) post-competition. ANOVA with repeated measures presented no difference for anxiety state between the competitive phases $(p>0.05)$. Motivation and PP were significantly higher during the final phase, tested by Friedman test $(p \leq 0.05)$. The data suggest competing in a final phase may lead to a major motivation and perceived of performance on professional contemporary dancers.
\end{abstract}

\begin{abstract}
RESUMO
O objetivo do estudo foi avaliar o efeito da fase da competição na ansiedade pré-competitiva, motivação e percepção de performance em dançarinos profissionais de dança contemporânea. Oito dançarinos profissionais da mesma companhia foram avaliados na condição basal, fase classificatória e final. O estado de ansiedade e motivação foram avaliados pré-competição e a percepção do desempenho (PP) pós-competição. ANOVA de medidas repetidas não apresentou diferença para $a$ ansiedade entre as fases competitivas $(p>0.05)$. Motivação e PP foram significativamente altas durante a fase final, testada pelo teste de Friedman ( $p \leq 0.05)$. Os dados sugerem que competir na fase final pode levar a uma maior motivação e percepção de performance em dançarinos contemporâneos profissionais.
\end{abstract}

\section{RESUMEN}

El objetivo del estudio fue evaluar el efecto de la fase de la competición en la ansiedad precompetitiva, motivación y percepción de desempeño en profesionales de danza contemporánea. Ocho bailarines profesionales fueron evaluados en la condición basal, fase clasificatoria y final. El estado de ansiedad y motivación fueron evaluados pre-competición y la percepción del desempeño (PP) post-competición. ANOVA de medidas repetidas no presentó diferencia para la ansiedad entre las fases competitivas ( $p>0.05$ ). Motivación y PP fueron significativamente altas durante la fase final, probada por Friedman $(p \leq 0.05)$. Los datos sugieren que competir en la fase final puede llevar a una mayor motivación y percepción de desempeño en bailarines contemporáneos profesionales.

Danza;

Competencia;

Ansiedad;

Desempeño.

\footnotetext{
a Midwest State University of Paraná, Department of Physical Education, Guarapuava, PR, Brazil.

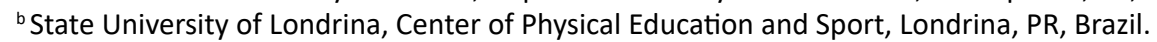

\author{
*Autor correspondente: \\ Ana Carolina Paludo \\ E-mail: anacpaludo@gmail.com
}

Recebido em 21 de Maio de 2019; Aceito em 18 de Julho de 2019. 


\section{INTRODUCTION}

Dance competition as a sport comprises a wide variety of dance styles and forms within an internationally recognized and organized competition structure (IDSF, 2011). One of dance modality that have been broadly practice in a recreational and professional context is the "Contemporary Dance". Contemporary dance emerged at the beginning of the $20^{\text {th }}$ century as a breakaway from the rigid constraints of classical ballet (Koutedakis e Jamurtas, 2004) and can be characterize by break with the traditional manifestations of the dance, such as the Ballet and Jazz. It shows a new world-view, a re-reading of pre-established concepts and a constant movement. Moreover, this modality of dance admits the aesthetics of freedom, in the sense of possessing innumerable ways of expressing, creating and producing dance (Silva 2005).

Similar to other sport-modalities, the contemporary dance may be classified as a high-intensity activity with great physical and physiological demand as well as an aesthetic performance (Wyon et al., 2004). Dance performance involve the culmination of several hours dedicated to training and practice to a best choreography presentation. Moreover, at the professional level, dancers must be psychologically prepared to handle the stress of choreography presentation during the competition (Angioi et al., 2009).

In the competition settings, the contextual factors may affect the behavioural and perceptual responses besides the competition outcomes (Arruda et al, 2018; Arruda et al., 2017). In team-sport athletes, the effect of contextual factor have been broadly investigate. Recently, basketball players demonstrated a lower perceived of anxiety level in easy match compared to moderate and hard matches, and lower self-confidence in hard match compared to training session (Arruda et al., 2017). Also, the players presented a high perceived of performance in the final match compared to regular match (Arruda et al., 2018).

On aesthetic sports such as the contemporary dance, the effect of contextual factors during competition still need to be better explored. Previous studies reported that ballet dancers present a higher intrinsic motivation to engage in professional dance (NordingBates et al., 2017), and hip-hop dancers perceived a better performance/competence in more taskinvolving motivate climate (Quested and Duda, 2009). However, to date, no previous studies investigated the behavioural and perceptual responses such as precompetitive anxiety and motivation and perceived of performance in contemporary dancers when they compete in different phase. Compete in classificatory and final phase maybe can be perceived as a threating or a challenging situation by professional dancers, which could in turn lead to high anxiety, motivation and performance responses.

Therefore, the present study was undertaken to evaluated the possible effect of the competition phase on pre-competitive anxiety and motivation state and perceived of performance in professional contemporary dancers. We hypothesized that the contextual factor of competition would lead the dancers to present a high anxiety state and motivation to compete the final competition phase ( $v s$. classification phase) accompanied by a great perception of performance.

\section{METHODS}

\section{Participants}

Eight subjects from a contemporary dance company ( male $=1$ and female $=7$ ) volunteered to participate in this study (age: $19.8 \pm 2$ years; experience: $9.7 \pm 3.5$ years). The dancers presented the same choreography during the competitions. The procedures were conducted with approval of the Ethics Committee of the local University ( $n^{\circ} 3.130 .343$ ), and the informed consent was obtained from each participant, prior to study commencement.

\section{Experimental design}

Before commencing the study, dancer were familiarized with all questionnaires used. The dancers presented the same choreography in three different conditions: in a local presentation, in a classificatory phase and in a final phase. The local presentation was considered as a basal condition (BC). The classificatory phase $(C P)$ consisted in a regional classificatory, and the final phase (FP) consisted in a Regional Championship named "Mostra Paranaense de Dança", that involved a competition with 174 dance companies classified in 05 regional phase. Approximately $35 \mathrm{~min}$ prior each competition, the cognitive and somatic anxiety and self-confidence, and the motivation to compete were assessed. After the presentation (approximately $30 \mathrm{~min}$ ), the dancers were required to register their perception of performance.

\section{Anxiety and self-confidence assessment}

The Revised Competition State Anxiety Inventory-2 (CSAI-2R) (Coxetal., 2003) was administered pre-presentation to estimate the dancers' cognitive and somatic anxiety as well as self-confidence levels. The CSAI-2R consist of 17 items scored on a 4-point Likert Scale (from 1= not at all to 4= very much so), derived 


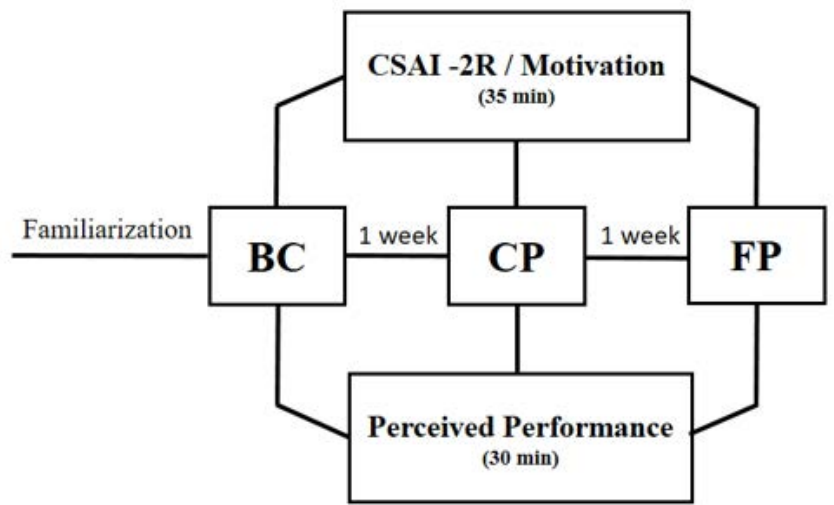

Figure 1. Study design. $\mathrm{BC}=\mathrm{Basal}$ Condition; $\mathrm{CP}=$ Classification Phase; FP= Final Phase; CSAI-2R= Revised Competition State Anxiety Inventory.

by asking each dancer "how do you feel right now - at this moment?". Cognitive anxiety was assessed from 5 items (intensity range: $5-20$ ), somatic anxiety from 7 items (intensity range: 7-28) and self-confidence from 5 items (intensity range: 5-20). A higher score related to cognitive and somatic anxiety indicates a high level of anxiety. An elevated score on the self-confidence subscale correspond to a high level of self-confidence. The dancers answered questions, such as "I am concerned about this competition (cognitive anxiety), "My body feels tense" (somatic anxiety), and "I am feeling self-confident" (self-confidence). The Cronbach's alpha coefficients of internal consistence were 0.84 for cognitive anxiety and self-confidence, and 0.88 for somatic anxiety reported elsewhere in Brazilian athletes (Fernandes et al., 2013). All dancers were familiarized with the questionnaire prior the competitions.

\section{Competition motivation assessment}

Competition motivation was evaluated after the anxiety questionnaire. The dancers were asked to answer the question "How would you rate your motivation to compete right now?" The motivational ratings ranged 0 to 4 point $(0=$ extremely low to $4=$ extremely high). Rating methods have been used to assess motivation in sports field, in both training and competition condition (Crewther et al., 2016; Crewther and Cook, 2018).

\section{Perceived of performance}

Dancers perceived performance (PP) was evaluated using a simple Likert Scale from 1 to 5 (1= worst performance to $5=$ best performance) based on their global performance during the presentation. This tool was conducted in accordance to previous study involving professional athletes (Cook et al., 2012; Arruda et al., 2018).

\section{Statistical analysis}

Data normality was checked using the Shapiro-Wilk's test. A one-way ANOVA with repeated measured was used to examine the differences in cognitive anxiety, somatic anxiety and self-confidence, separately, between competitions. To analyse the Liker-type rating scales such as dancers' motivation and perceived of performance the non-parametric approach was chosen for demonstrating a major power in small sample size (Kaptein et al., 2010), therefore the Friedman test was used for within-subject comparison across the competitions (Kim, 2014). The SPSS software (v. 20.0, SPSS Inc., Chicago, IL, USA) was used for data analyses. Statistical significance was set at $P \leq 0.05$.

\section{RESULTS}

Figure 2 present the results (mean and SD) of cognitive (Fig. 2A) and somatic (Fig. 2B) anxiety state. Figure 3 present the results (mean an SD) of selfconfidence state. No statistical difference was found between the conditions for anxiety cognitive, anxiety somatic and self-confidence $(P>0.05)$.

Figure 4 present the results (mean and SD) of dancers' motivation (Fig.4A) and perceived of performance (Fig. 4B). A significant difference was observed between competitions for both motivation $\left(X^{2}=9.680, p \leq 0.05\right)$ and perceived of performance $\left(X^{2}\right.$ $=10.571, p \leq 0.05)$ in which a higher motivation and perceived performance were observed for competition 3 compared to competition 1.

\section{DISCUSSION}

Studies regarding dancers behaviour or perception have been focus their investigation into psychological characteristic and skills (Nordin, 2008), no considering, in the most of time, the responses of dancers in a competition settings. Therefore, the present study investigated the effect of competition phase on anxiety state and motivation and perceived performance in professional contemporary dancers. The main results were: a) the dancers demonstrated a higher motivation and greater perceived of performance competing in a final phase ( $v s$ basal condition); b) pre-competitive cognitive anxiety, somatic anxiety and self-confidence seems not to be affected by the competition phase in dancers.

In sport, competition settings present some contextual factors that can influence the behavioural and perceptual responses, besides the performance. Researches in team-sports competition reported an association of status-seeking behaviours and gaining or maintaining social status, in which the perceptual 
A)

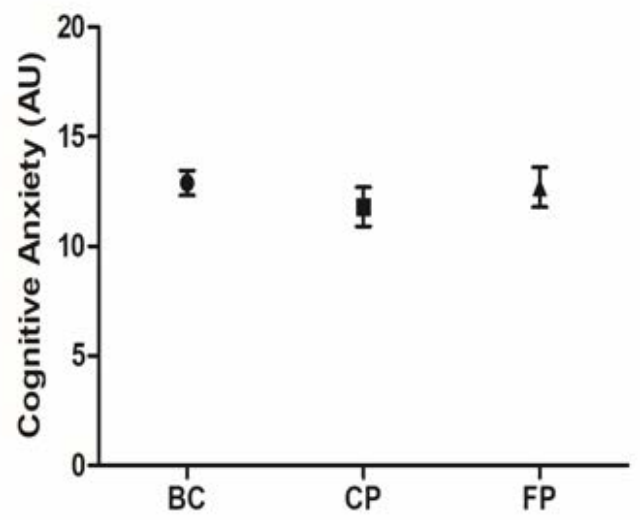

B)

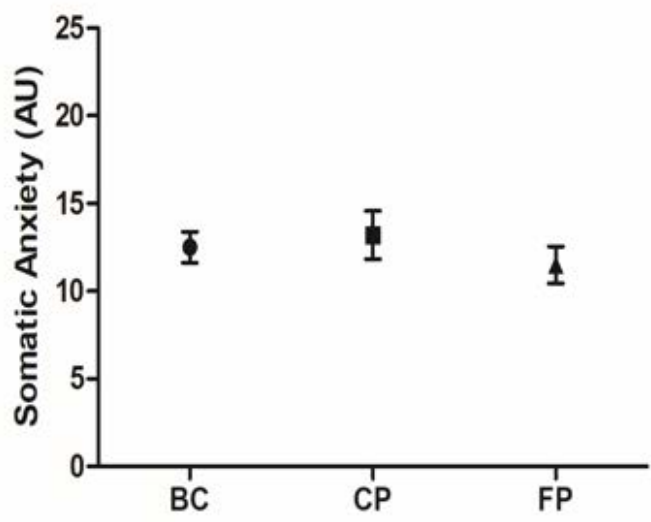

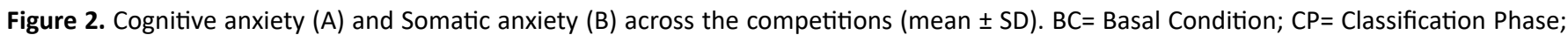
$\mathrm{FP}=$ Final Phase. $\mathrm{AU}=$ arbitrary units.

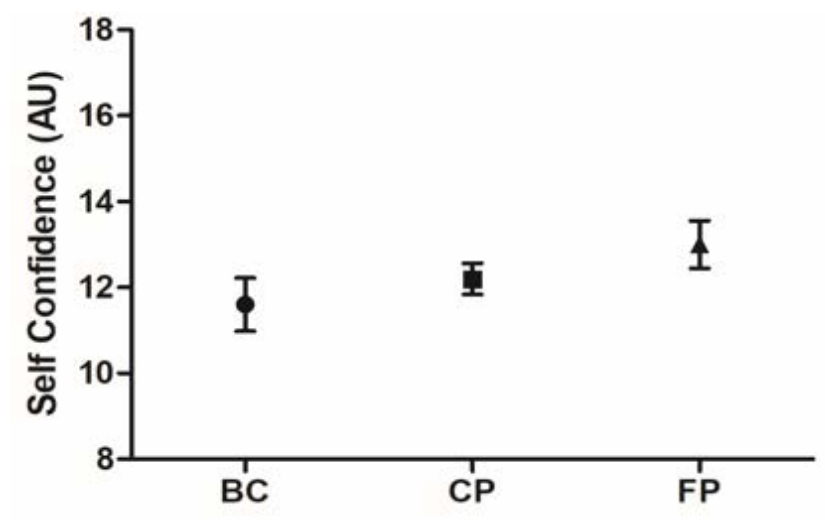

Figure 3. Self-confidence across the competitions (mean $\pm S D$ ). $B C=$ Basal Condition; $\mathrm{CP}=$ Classification $\mathrm{Phase} ; \mathrm{FP}=$ Final $\mathrm{Phase}$. $\mathrm{AU}=$ arbitrary units.

responses may be more influenced by the competition stage (Arruda et al., 2018) as well as the opponent level (Arruda et al., 2017). However, the behaviourcompetition relationship in dancer competition settings it is not well-established yet. Dance competition has a different component compared to

\section{A)}

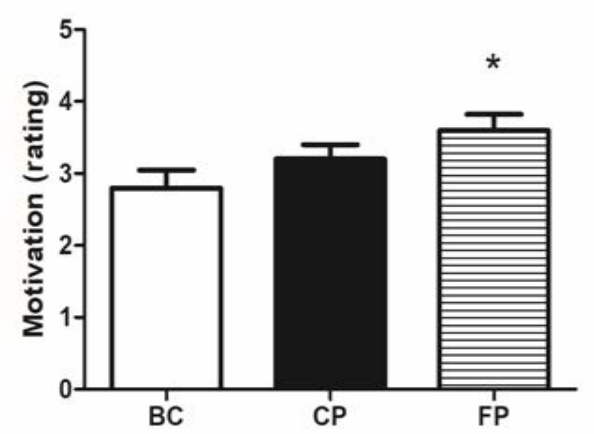

team-sport competition: the aesthetics performance. As mentioned, contemporary dance competition require a near to perfect choreography performance that involves creativity and aesthetic presentation. Therefore, the appearance may play an important role in best performance and this factor may triggers motivation and anxiety level for social status-seeking in high competition.

The anxiety pre-competition is one of the most investigated topic in sport psychology. The literature have been demonstrating that the anxiety may vary upon some competition factors, such as competition phase (Arruda et. 2017). However, the relationship between anxiety-performance in professional dancer upon competition' contextual factor still a gap. Treating appraisals were related to high levels of cognitive and somatic anxiety in male and female dancers (Quested et al., 2011). In the present study, pre-competitive anxiety and self-confidence did not differ between the competition phases, demonstrating that dancers

B)

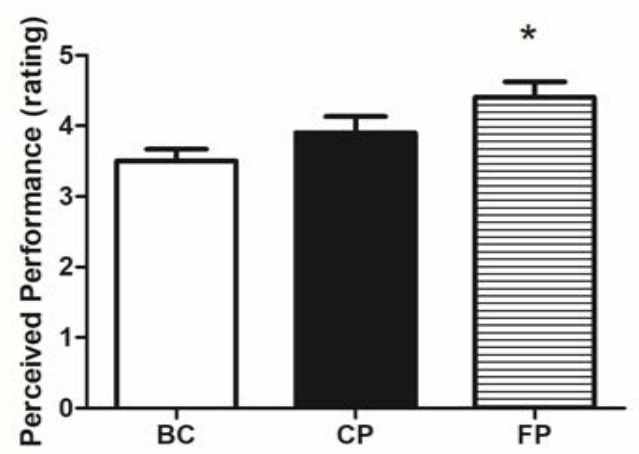

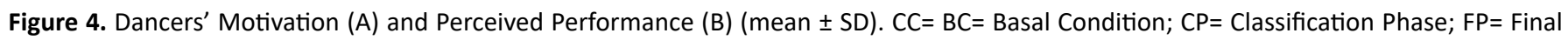
Phase. * significantly different from BC. 
maybe have a coping strategy to deal with anxiety pre-competition. Also, the design of competition and presentation, familiarity with the programmed choreography could have influenced on dancer' anxiety and self-confidence. No significant difference also was found in a study involving modern dance men in rehearsal and dance competition. The authors reported that the modern dancers showed similar anxiety levels either performing in a competition with rival, in front of judges and audience or in the final rehearsal (Keer et al., 1999).

On the other hand, perceptual responses to motivation and performance seems to be affect by the competition phase. Dancers in the present study presented higher motivation to compete in the final phase ( $v s$ basal condition) as well as better perceived of their performance. It could be speculate that these responses were influenced by the social status-seeking behaviors, in which the dancers' goal to gain or maintaining their social status, especially in the most important competition.

Challenging and/or treating situations seems to lead the dancers to a high motivation compared to opposite one, following by a high perception of competence. Previous study with hip-hop dancers demonstrated that motivational climate promote feelings of personal mastery. The authors suggested that when dancers participate in a task-involving atmosphere their perceptions of competence is more likely to be reinforced (Quested and Duda, 2009). A speculative explanation for this behaviour can be justify by dancer's personality. It was reported elsewhere that professional dancer present high scores of perfectionism and this perfectionism behaviour could be related to concern of a choreography near to perfect. Moreover, perfectionist dancers reported higher intrinsic motivation compared to the nonperfectionist dancers (Nordin-Bates et al., 2017).

The present study has some methodological limitation that should be taken into account. First, the selection of one contemporary dance company limited the present findings to the specific sample; therefore, the finding of the present study must be interpreted with caution in other dance modalities. Second, we did not control some psychological variables such as personality, perception of competition level and so on. Moreover, we do not controlled the maturation phase and the women menstrual cycle phase. Maybe this information may help to better understand the behavioural response to competition phase factor. Besides the limitation, it is important to emphasize that the present study is the first to analyse the precompetitive anxiety, motivation and perceived of performance in contemporary dancers, considering the phase competition, aiding to understand the behavioural and perceptual responses to contextual factor on competition settings.

\section{CONCLUSION}

The present findings indicated that the competition phase affect pre-competition motivation and the perceived of performance but not the anxiety state. Competing in a most challenging or treating phase seems to cause higher motivation in professional dancers, and this perceived of motivation seems to lead a better perceived of competence regarding the choreography presentation. These results suggests that competition stage play an important role on perceived social-seeking in contemporary dancers.

\section{REFERENCES}

Angioi M, Metsios G, Koutedakis $Y$, \& Wyon MA. Fitness in contemporary dance: a systematic review. International Journal of Sports Medicine, 2009; 30:475-484.

Arruda AF, Aoki MS, Paludo AC, Moreira A.Salivary steroid response and competitive anxiety in elite basketball players: effect of opponent level. Physiology \& behaviour 2017;177:291-296.

Arruda FS, Aoki, MS, Paludo AC, Drago G, Moreira A. Competition stage influences perceived performance but does not affect rating of perceived exertion and salivary neuro-endocrine-immune markers in elite young basketball players. Physiology \& behaviour 2018;188:151-156.

Cook CJ, Crewther BT. The effects of different pre-game motivational interventions on athlete free hormonal state and subsequent performance in professional rugby union matches. Physiology \& behaviour 2012;106:683-688.

Cox RH, Martens MP, Russell WD. Measuring anxiety in athletics: The revised competitive state anxiety inventory-2. Journal of Sport \& Exercise Psychology 2003; 25:519-533.

Crewther BT, Cook CJ. A longitudinal analysis of salivary testosterone concentrations and competitiveness in elite and non-elite women athletes. Physiology \& behavior 2018;188:157-161.

Crewther BT, Carruthers J, Kilduff, LP, Sanctuary CE, Cook CJ. Temporal associations between individual changes in hormones, training motivation and physical performance in elite and non-elite trained men. Biology of sport 2016;33:215.

Fernandes MG, Nunes AS, Raposo JV, Fernandes HM, Brustad R. The CSAI-2: An examination of the instrument's factorial validity and reliability of the intensity, direction and frequency dimensions with Brazilian athletes. Journal of Applied Sport Psychology 2013;25:377-391.

International Dance Sport Federation. 2011. Dance Sport for all. Retrieved from http://www.worldwancesport.org/ about/all.

Kaptein MC, Nass C, Markopoulos P. Powerful and consistent analysis of likert-type ratingscales. In Proceedings of the SIGCHI Conference on Human Factors in Computing Systems. ACM, 2010;2391-2394. 
Kerr JH, Kawaguchi C, Oiwa M, Terayama Y, Zukawa A. Stress, anxiety and other emotions in Japanese modern dance performance. South Pacific Journal of Psychology, 1999; 11:1, 16-33.

Kim HY. Statistical notes for clinical researchers: Nonparametric statistical methods: 2. Nonparametric methods for comparing three or more groups and repeated measures. Restorative Dentistry \& Endodontics 2014;39:329.

Koutedakis $Y$, Jamurtas $A$. The dancer as a performing athlete: physiological considerations. Sports Medicine 2004;34:651-661.

Nordin SM, Cumming J. Exploring Common Ground: Comparing the Imagery of Dancers and Aesthetic Sport Performers, Journal of Applied Sport Psychology, 2008; 20:4,375-391

Nordin-Bates SM, Raedeke TD, Madigan DJ. Perfectionism, burnout, and motivation in dance: $A$ replication and test of the $2 \times 2$ model of perfectionism. Journal of Dance Medicine \& Science 2017;21:115-122.

Quested E, Duda JL. Perceptions of the motivational climate, need satisfaction, and indices of well-and ill-being among hip hop dancers. Journal of Dance Medicine \& Science 2009;13:10-19. Quested E, Bosch JA, Burns VE, Cumming J, Ntoumanis N, Duda JL. Basic psychological need satisfaction, stress-related appraisals, and dancers' cortisol and anxiety responses. Journal of Sport and Exercise Psychology, 2011; 33:6, 828-846.

Silva ER. Dança e pós-modernidade. EDUFBA, Editora da Universidade Federal da Bahia, 2005.

Wyon MA, Abt G, Redding E, Head A, Sharp NCC. Oxygen uptake during modern dance class, rehearsal, and performance. The Journal of Strength \& Conditioning Research 2004;18:646-649. 